\title{
Improvement of dry tropical rangelands on Hainan Island, China: 4. Effect of seedbed on pasture establishment
}

\author{
DAVID L. MICHALK, FU NAN-PING, AND ZHU CHIN-MING
}

Authors are former director, former pasture technician, and production manager of Gaopoling Model Cattle Farm, Ba Suo, Dong Fang County, Hainan Island, People's Republic of China.

\begin{abstract}
Seedbed requirements for the establishment of grasses and legumes were studied in 3 experiments conducted over 3 years (1981-83) on the sandy (< $5 \mathrm{mg} \mathrm{kg}^{-1}$ Bray P) and loam ( $20 \mathrm{mg}$ $\mathrm{kg}^{-1}$ Bray P) ultisol soils found in the dry tropical rangelands of western Hainan Island, China. Density at the end of the wet season and production accumulated over the growing season (May-October) were the discriminative parameters used. Experiment 1 measured the effect of seedbed preparation (cultivated and uncultivated but heavily grass pasture) on the establishment of 2 grasses, buffel (Cenchrus ciliaris L. cv. Biloela) and sabi (Urochloa mosambicensis (Hack.) Dandy cv. Nixon), sown alone or mixed with 3 stylos (Stylosanthes guianensis (Aubl.) Sw. var, guianensis cv. Gratum, S. hamata (L.) Taub. cv. Verano and S. scabra Vog. cv. Seca) on the 2 soil types. Biloela buffel established better and produced more in subsequent years than Nixon sabi grass when sown on a cultivated seedbed, but neither grass established when sown into undisturbed grassland. Companion stylos established on both seedbeds, but initial density and yield was lower on the uncultivated seedbed. However, in 3-year-old swards, stylo yield on uncultivated seedbeds equalled or exceeded yield on cultivated seedbeds. Seca was the most productive stylo, but Graham yielded more consistently between years. Soil type had no effect on sown grass production, but legumes grew better on the sandy soil. Experiment 2 measured the effect of 4 seedbeds (heavily grazed, 1 disking, sprayed with herbicide, and cultivated to fine tilth) on establishment on Verano and Seca stylos on sandy soil. Density of both stylos was highest where grass competition was minimized with herbicide and lowest where heavy grazing was imposed prior to seeding. Compared to herbicide, disking resulted in lower density and yield in the establishment year, but the difference disappeared with time. Burial of seed too deeply and subsequent competition from native species account for the poor performance of both stylos when drilled into a cultivated seedbed which was still evident in 3-year-old swards. Experiment 3 examined the interaction between seedbed type
\end{abstract}

\footnotetext{
The authors wish to thank Huang Zhen-Sheng, former manager of Gaopoling Farm, for providing facilities for the experimental program and the Pasture Production Team for assisting with the field work. The vital communication link provided by interpreters Deng Zhou-Lien and Yen Ren-Chang between Australian advisers and their Chinese counterparts is gratefully acknowledged. DLM also thanks other members of the Australian team at Gaopoling Farm, Dr. J.F. Ayres and Mr. S.E. Dunn and NSW Agriculture Overseas Project Director, Mr. G.D. Slennett, for their support and encouragement. The work was conducted under the auspices of the NSW-Guangdong Sister Government Agreement. The statistical advice provided by Ms. H. Nicol is also gratefully acknowledged.

Manuscript accepted 27 Feb. 1997.
}

(heavily grazed, burnt, 1 disking, sprayed with herbicide) and superphosphate application. Superior establishment was measured on herbicide and disked treatments and production was still higher in 3-year-old swards than heavy grazing. Burning was more effective than heavy grazing. Increasing fertilizer input improved legume production on all seedbeds, but did not affect density. Reduction in legume yield between 2 - and 3-year-old swards in the burnt and disked treatment due to grass competition highlights the need for appropriate grazing to maintain legume content of augmented grasslands. Overall we recommend rough disking as the most practical and cost-effective means to augment native grasslands with stylos. A fine seedbed is recommended to provide the disturbance required to establish grasses. There is no advantage gained by including grasses with legumes oversown into living grassland.

Key Words: China, dry tropical, seedbed, cultivation, burning, herbicide, grasses, legumes

It is important to determine the cheapest, low risk methods of pasture establishment in tropical areas so that farmers will be encouraged to improve their pastures and cattle productivity (Hutton 1979). To date, little research has been conducted in south China to identify the most efficient means of introducing improved grasses and legumes into rangelands set aside under government policies for beef production.

Wherever possible the existing grassland should not be destroyed during range improvement programs. This not only lowers development costs, but also provides cattle forage during the improvement phase. In Australia, Stylosanthes and Macroptillium species are most often established by oversowing seed into the ash of burnt or heavily grazed grass-dominant native pastures (McIvor 1983). Since these legumes are also highly adapted to the dry tropical rangelands of western Hainan Island (Michalk et al. 1993a), the potential of low-cost sowing methods needs to be tested in south China.

While the application of superphosphate and broadcast sowing of stylos have significantly increased beef output in tropical areas (Hutton 1979, Walker 1983), Australian experience indicates that the increased grazing capacity may lead to pasture instability (Andrew 1988) caused by a decline in the native perennial grasses (Ritson et al. 1971, Winks et al. 1974). More competitive and robust grasses are desirable components of range vegetation because they provide stability and prevent ingress of woody weeds (Norman 1967). 
The ability to establish readily with minimum seedbed preparation and low fertilizer inputs has become an important criteria to select better perennial grasses for dry tropical environments. However, in contrast to legumes, research suggests that considerable disturbance of the existing vegetation is necessary for satisfactory establishment of improved grasses (McIvor and Gardener 1981, Thomson et al. 1983) such as buffel grass (Cenchrus ciliaris L.) and sabi grass (Urochloa mosambicensis (Hack.) Dandy). Nevertheless, it is not known if this also applies to rangelands on Hainan Island where the soil types and native grasses are different from those found in northern Australia.

The aim of the 3 experiments reported in this paper was to determine the effect of a range of seedbed preparations on the establishment of 3 legumes and 2 grasses on the 2 main soil types found in the rangelands of western Hainan Island. The interaction between seedbed preparation and fertilizer application was also investigated.

\section{Material and Methods}

\section{Site}

The experiments were conducted at Gaopoling Model Cattle Farm $\left(19^{\circ} 09^{\prime} \mathrm{N} ; 108^{\circ} 68^{\prime} \mathrm{W}\right)$ which is located in the dry tropical region of western Hainan Island, People's Republic of China. The $1,001 \mathrm{~mm}$ annual rainfall is typical of the dry tropics with $85 \%$ received in the mid-May to mid-October period. The soils on the site range from deep siliceous sands on the coastal plain to red loams in the undulating hinterland. Both types were included in this study. These conditions, which are representative of the 162,000 ha set aside in dry tropical Hainan Island for improvement for range-based cattle production, are described in detail by Michalk et al. (1993a).

\section{Existing Vegetation}

The vegetation of the coastal plain of western Hainan Island is defined as a savanna (Grubov 1969) with Heteropogon contortus (L.) Beauv. ex Roem. \& Schult, Aristida chinensis Munro. and Eragrostis elongata Jacq. as dominant grasses (Hu et al. 1992) in the interspaces between a range of scrubs (Michalk et al. 1993a) and a few trees. In addition to these dominants, other grasses include: Cynodon dactylon (L.) Pers., Digitaria longiflora (Retz.) Pers., Imperata cylindrica (L.) P. Beauv. and Paspalum orbiculare G. Foster. Cymbopogon caesius Stapf., Eulalia quadrinervis Kuntze. and Ischaemum aristatum L. are also found but only on the red loam soil. Few legumes are found in undisturbed grasslands, but with heavy grazing there is a steady increase with Alysicarpus vaginalis (L.) DC., Indigofera hirsuta L. and Desmodium triflorum (L.) DC. being the most important. D. triflorum, a prostate legume which resists grazing and grows well with short grasses, is the dominant legume on the sandy soil.

\section{General Experimental Procedures}

Experiments 1 and 3 were conducted as cutting studies on $4 \times$ 4-m plots replicated 3 times, whereas Experiment 2 was conducted as a field demonstration using 2-ha paddocks. Cattle were used each year to remove accumulated growth just prior to rain at the end of the dry season in Experiments 1 and 3 but werc set stocked at 2 animal units (AU) ha ${ }^{-1}$ in Experiment 2 from November 1981 to the end of the study.
Legume seed was dehulled, scarified using hot water treatment, inoculated with commercial Rhizobia in peat, and pelleted with rock phosphate prior to surface broadcasting at a rate of $6 \mathrm{~kg} \mathrm{ha}^{-1}$. A germination percentage of $>85 \%$ was obtained for both legumes using a standard test. Grasses were also surface sown at $6 \mathrm{~kg} \mathrm{ha}^{-1}$ in Experiment 1, and both had a germination percentage of $28 \%$.

Experiments 1 and 2 were fertilized with local Grade 4 superphosphate (28 $\mathrm{kg} \mathrm{P} \mathrm{ha}^{-1}$ ) at sowing. Four rates of superphosphate were used in Experiment 3. No maintenance fertilizer was applied to these experiments over the study period.

Dry matter production was measured at the end of the wet season by cutting four $0.5 \mathrm{~m}^{2}$ quadrats/plot with hand shears to a height of $5 \mathrm{~cm}$. Harvested material was weighed, sorted into species components, and dried to determine dry matter content and botanical composition by weight. Plant density was estimated by counting the number of sown species present in four, $0.5 \mathrm{~m}^{2}$ quadrats/plot at the end of the wet seasons in 1981 and 1982 in Experiments 1 and 3, and in 100 quadrats in Experiment 2. Total yield and botanical composition of all treatments were monitored over 3 seasons (1981-83).

Analyses of variance split in time were set up in the Genstat program (Payne et al. 1988) to analyse density and production data. Least significant differences based on error terms from the appropriate stratum of the analyses of variance for pasture parameters were used to differentiate between significant and non-significant means. Linear and nonlinear regressions were used to examine relationships between sown legume performance and density.

\section{Experiment 1}

The effect of seedbed preparation on grass establishment and subsequent production was examined in a 3 way split design with 2 soil types (sandy and red loam) and 2 seedbed types (cultivated and heavily grazed but uncultivated) as main-plots, and 3 grass (native grasses; Urochloa mosambicensis-sabi grass cv. Nixon and Cenchrus ciliaris-buffel grass cv. Biloela) and 4 legume (volunteer naive legumes; Stylosanthes guianensis (Aubl.) Sw. var. guianensis cv. Graham, S. hamata (L.) Taub. cv. Verano and $S$. scabra Vog. cv. Seca) treatments as sub-plots.

The cultivated seedbed was prepared by ploughing twice with offset discs and once with a tyned scarifier. Seed was surface broadcast with fertilizer and raked lightly on 10 July 1981 . The uncultivated area was heavily grazed with cattle and the seed broadcast with fertilizer into the short pasture which remained (about $0.5 \mathrm{t} \mathrm{DM} \mathrm{ha}^{-1}$ ).

\section{Experiment 2}

The effect of seedbed preparation on the establishment of Verano and Seca stylos was investigated further on sandy soil in a split-plot design with seedbed preparations as main plots and legume species as sub-plots. The seedbed treatments included:

(1) Control-heavily grazed with cattle;

(2) Disked-rough seedbed prepared by cultivating with 1 pass with offset disks

(3) Herbicide-regrowth was sprayed with glyphosate $(1.4 \mathrm{~kg}$ ha $^{-1}$ active ingredient) 21 days after heavy grazing by cattle; and,

(4) Cultivated-fine seedbed prepared by disking followed by cultivation.

Legume seed and fertilizer were mixed and broadcast onto the surface of treatments 1 to 3 using a fertilizer spinner on 25 July 
1981. Treatment 4 was sown with a drill which placed the legume seed and fertilizer at about $1 \mathrm{~cm}$ below the soil surface. Density and production were measured in 13 sampling areas located on the diagonal transects of each of the 2-ha plots.

\section{Experiment 3}

The interaction between seedbed preparation and fertilizer application on establishment and subsequent production of Verano stylo was examined on the sandy soil only. The experimental site which had good cover of native grasses (about $80 \%$ ) was selected in May 1981 just prior to the start of the wet season and the following seedbed preparations were imposed:

(1) Control-heavily grazed with cattle;

(2) Burnt-no further treatment;

(3) Cultivated-rough seedbed prepared by cultivating with 1 pass with offset disks; and

(4) Herbicide-regrowth was sprayed with glyphosate $\left(2 \mathrm{~kg} \mathrm{ha}^{-1}\right.$ active ingredient) 21 days after heavy grazing by cattle and 2 days before sowing.

The experimental design was as split-plot design with seedbed preparations as main plots and 4 rates (in $\mathrm{kg} \mathrm{P} \mathrm{ha}^{-1}$ ) of superphosphate (P0, P7, P14, and P28) as sub-plots. All treatments were broadcast with Verano stylo on 15 July 1981.

\section{Results}

\section{Experiment 1}

\section{Establishment}

Density (plants $\mathrm{m}^{-2}$ ) of sown species present at the end of wet season in 1981 was used as a measure of initial establishment. Re-sampling in November 1982, provided an indication of survival and recruitment.

Grasses: Seedbed preparation significantly impacted grass establishment. Both grasses failed to establish when broadcast on the uncultivated seedbed, but established reasonably well on the cultivated seedbed prepared on both soils with densities in the range of 3 to 35 plants $\mathrm{m}^{-2}$ (Table 1 ).
Buffel established at twice the density of sabi grass. Soil type also affected grass establishment with twice as many sown grass plants present on the sandy soil compared to the red loam (Table 1). Of the companion stylos sown only Verano affected grass density reducing buffel density by $45 \%$ and sabi grass by $25 \%$. However, this effect was not carried through to 2-year-old pastures.

Sward age affected grass density on the sandy soil where numbers of buffel grass were reduced 28 to $44 \%$, except when grown with Verano where density increased with time (Table 1). On loam soil, however, there was no difference between the densities of either grass in 1- or 2-year-old swards which developed on the cultivated seedbed.

Legumes: Stylos established better than grasses on both seedbeds (Table 1). However, like the sown grasses, legume density was reduced by up to $50 \%$ or more on the uncultivated seedbed. Densities of Graham and Seca stylos were similar, but the overall density of Verano was significantly lower $(P<0.05)$. Companion grass did not affect density of any of the stylos.

Survival and recruitment were similar between the 1981 and 1982 measurements for all of the stylu cultivars on loam soil, irrespective of seedbed type. However, on sandy soil density of all stylos declined $(P<0.05)$ between 1981 and 1982 where the seedbed was cultivated, but only for cv. Graham when sown on the uncultivated seedbed (Table 1).

\section{Production}

Sown grasses: Seedbed significantly affected $(\mathrm{P}<0.05)$ sown grass performance (Table 2). Introduced grasses did not produce any measurable yield in treatments broadcast on the uncultivated seedbed on either soil type (Fig. 1). On the cultivated seedbed, production of buffel and sabi was also low (mean $<0.13 \mathrm{t} \mathrm{ha}^{-1}$ ) in the establishment year, but yields of both sown grasses improved $(\mathrm{P}<0.01)$ over time with production exceeding $2 \mathrm{t} \mathrm{ha}^{-1}$ of sown grass in some treatments by the end of the study (Fig. 1).

Buffel was superior to sabi grass on both soil types $(P<0.05)$, producing on average about $60 \%$ more dry matter. This was due to significantly higher production in 2- and 3-year-old swards.

Table 1. Establishment for sown grass only, sown legume only, and sown grass/legume mixtures sown on cultivated and uncultivated seedbeds on sandy and loam soils at Gaopoling Farm, 1981-1982 (Experiment 1).

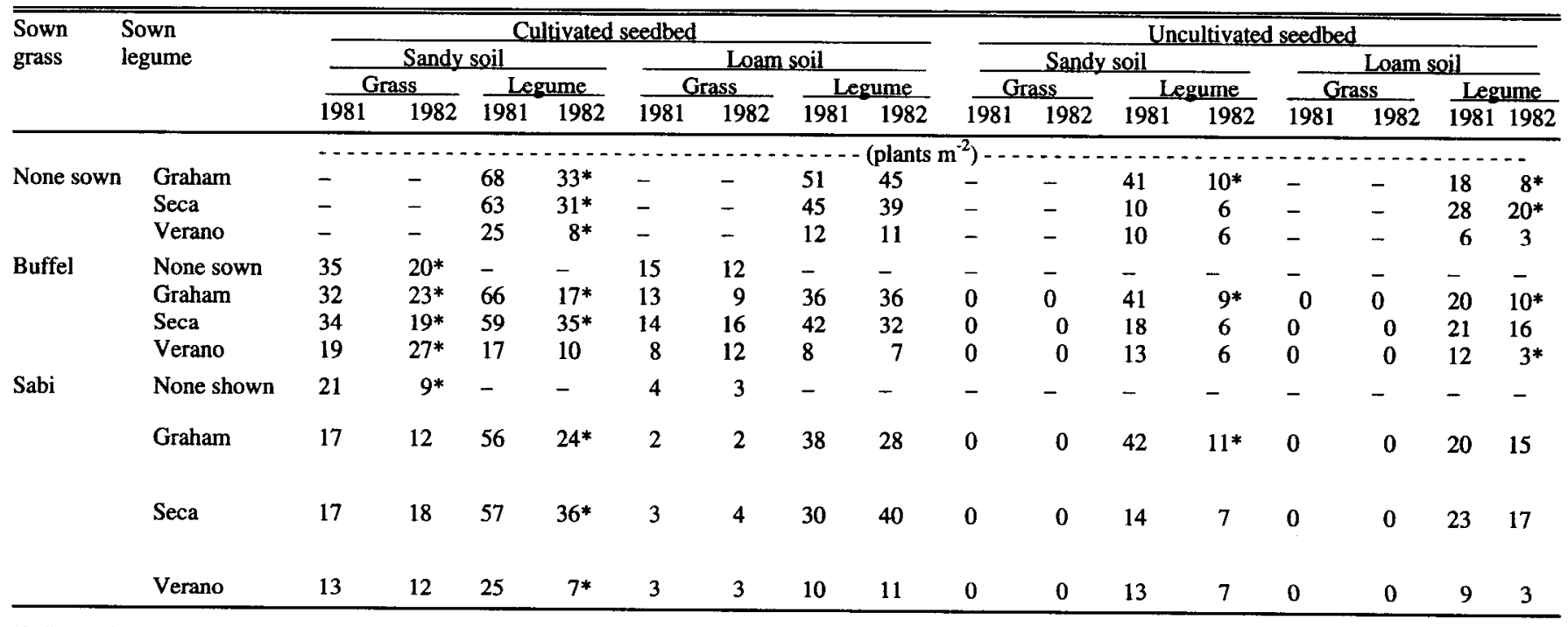

*indicates significant difference at $\mathrm{P}<0.05$ in mean density of grasses or legumes between years within pasture component, grass species, legume species, soil type, and seedbed type. 
Table 2. Means for main effects of production for grass/legume mixtures sown on cultivated and uncultivated seedbeds on sandy and loam soils at Gaopoling Farm, 1981-1983 (Experiment 1).

\begin{tabular}{llllll}
\hline \hline Main & & \multicolumn{4}{c}{ Parameter } \\
\cline { 4 - 6 } Fffect & Comparison & Grass $^{1}$ & Legume $^{1}$ & Other spp. Total \\
\hline \multirow{3}{*}{ Seedbed } & Cultivated & $0.49 \mathrm{a}$ & $1.75 \mathrm{a}$ & $0.95 \mathrm{~b}$ & $3.19 \mathrm{a}$ \\
& Uncultivated & $0.00 \mathrm{~b}$ & $1.21 \mathrm{~b}$ & $1.11 \mathrm{a}$ & $2.32 \mathrm{~b}$ \\
Soil type & Sand & $0.23 \mathrm{a}$ & $1.30 \mathrm{~b}$ & $0.78 \mathrm{~b}$ & $2.31 \mathrm{~b}$ \\
& Loam & $0.26 \mathrm{a}$ & $1.66 \mathrm{a}$ & $1.27 \mathrm{a}$ & $3.19 \mathrm{a}$ \\
Legume & None sown & $0.22 \mathrm{~b}$ & $0.36 \mathrm{~d}$ & $1.02 \mathrm{~b}$ & $1.60 \mathrm{~d}$ \\
& Graham & $0.34 \mathrm{a}$ & $1.76 \mathrm{~b}$ & $1.11 \mathrm{ab}$ & $3.21 \mathrm{~b}$ \\
& Seca & $0.25 \mathrm{ab}$ & $2.95 \mathrm{a}$ & $0.84 \mathrm{c}$ & $4.04 \mathrm{a}$ \\
& Verano & $0.18 \mathrm{~b}$ & $0.87 \mathrm{c}$ & $1.15 \mathrm{a}$ & $2.20 \mathrm{c}$ \\
Grass & None sown & $0.00 \mathrm{c}$ & $1.54 \mathrm{a}$ & $1.16 \mathrm{a}$ & $2.70 \mathrm{a}$ \\
& Buffel & $0.46 \mathrm{a}$ & $1.43 \mathrm{a}$ & $0.94 \mathrm{~b}$ & $2.83 \mathrm{a}$ \\
& Sabi & $0.28 \mathrm{~b}$ & $1.48 \mathrm{a}$ & $0.99 \mathrm{~b}$ & $2.75 \mathrm{a}$ \\
& 1981 & $0.07 \mathrm{~b}$ & $0.53 \mathrm{c}$ & $1.08 \mathrm{a}$ & $1.68 \mathrm{c}$ \\
Year & 1982 & $0.37 \mathrm{a}$ & $2.67 \mathrm{a}$ & $1.08 \mathrm{a}$ & $4.12 \mathrm{a}$ \\
& 1983 & $0.30 \mathrm{a}$ & $1.25 \mathrm{~b}$ & $0.93 \mathrm{~b}$ & $2.48 \mathrm{~b}$ \\
\hline
\end{tabular}

Main effects means within parameters followed by the same letter are aot significantly different at $P<0.05$; ' refers to sown species.

Soil type did not affect yield of either grass. Companion legumes significantly affect grass production: on both soils legumes increased $(P<0.05)$ buffel yield in 2 - and 3-year-old pastures (Fig. 1).
Sown legumes: Seedbed preparation, soil type, and year significantly affected ( $\mathrm{P}<0.05$ ) legume performance (Table 2 ). Production of the 3 stylos was higher $(\mathrm{P}<0.01)$ in the establishment year when broadcast on a cultivated seedbed on both soils (with and without improved grasses) compared to yields on the uncultivated seedbed (Fig. 1). Although the establishment year production of all stylos was $<0.3 \mathrm{t} \mathrm{ha}^{-1}$ when broadcast on the heavily grazed but uncultivated seedbed, stylo yield on 3-year-old pastures were equivalent to or higher than production measured on the cultivated areas (Fig. 1).

The full effect of soil type $x$ seedbed interaction on legume production was masked by a wildfire which burned the loam site in late August 1983, and reduced $(P<0.05)$ yields of Verano and Seca below those measured on sandy soil (Fig. 1). Graham stylo was least affected by fire.

Sown legumes produced between 2 and 8 times more forage than volunteer native legumes. Seca was the most productive of the sown legumes (Table 2), but Graham produced consistently between years (Fig. 1).

Endemic grasses and forbs: Grasses accounted for more than $90 \%$ of the "other" component on both soil types. However, bunch grasses dominated the red loam site and stoloniferous sodformers were more prevalent on sandy soil. More $(P<0.05)$ native grasses and forbs were found on the uncultivated seedbed and on the loam soil. Yield of volunteer species was reduced

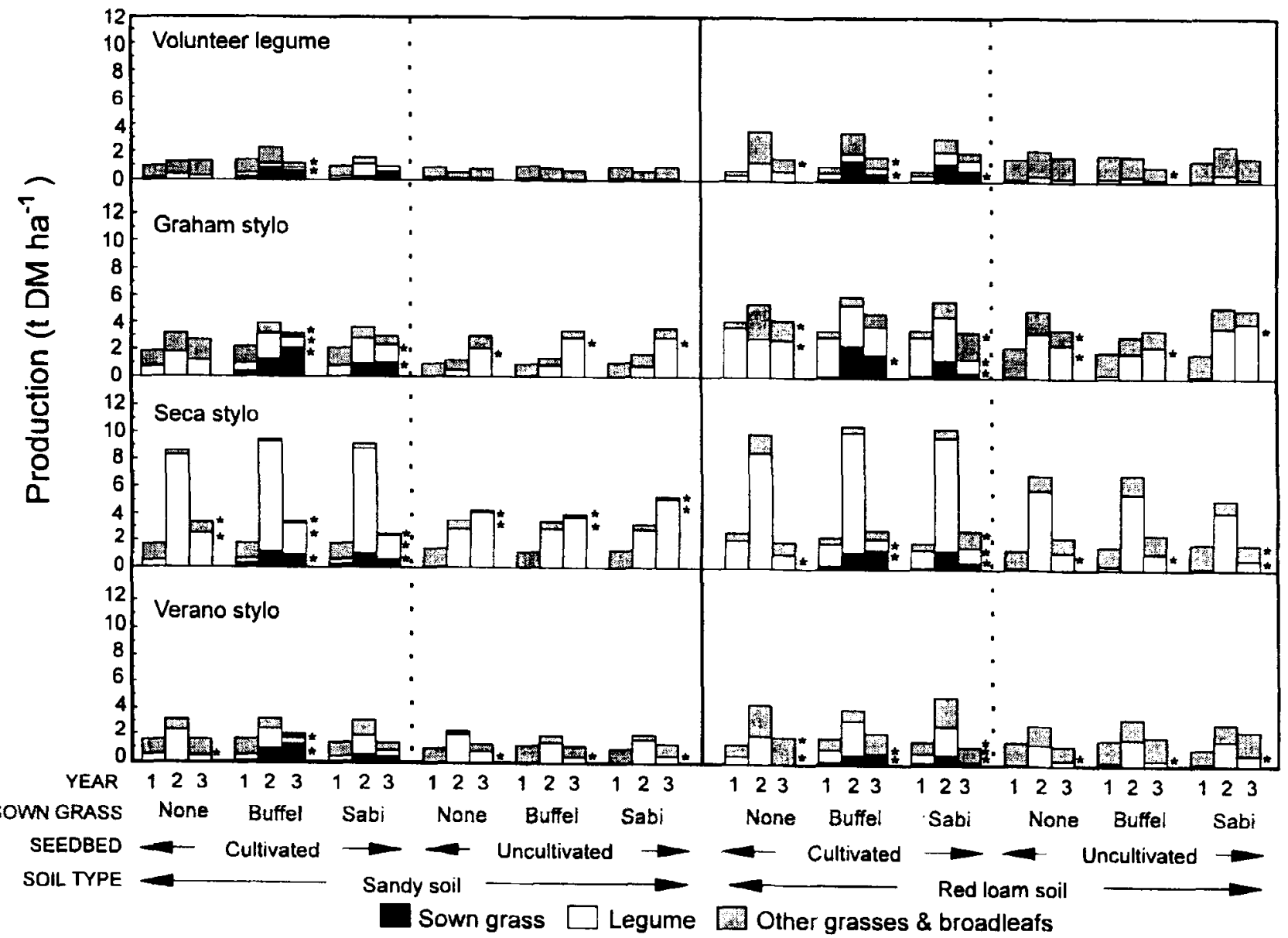

Fig. 1. Production for grass only, legume only and grass/legume mixtures sown on cultivated and uncultivated seedbeds on sandy and loam soils at Gaopoling Farm, 1981-1983 (Experiment 1). Asterisk indicate significant differences at $P<0.05$ in sown grass, legume or "other species" production hetween years within sown grass treatments. 
when legumes were broadcast with grasses, especially Graham and Seca (Fig. 1).

Total yield: Seedbed preparation, legume species, soil type, and age of sward all significantly affected $(P<0.05)$ total yield accumulated over the growing season in each year. Overall total yield was $38 \%$ higher on a cultivated seedbed and twice as high on loam compared to sandy soil (Table 2). Legume species impacted total yield, especially Seca which produced $>200 \%$ more forage than the control on sandy soil on both seedbed types, and about $100 \%$ more on loam soil. However, this superiority was due mainly to the high production of Seca in 1982 when the legume accounted for > $90 \%$ of total yield (Fig. 1). Although Graham stylo produced only half of the yield of Seca-based pastures, total production was distributed better between years (irrespective of seedbed type-Fig. 1) which would be an advantage for cattle production.

\section{Experiment 2 \\ Establishment}

Overall densities of Verano and Seca were low and establishment in 1981 accounted for less than $1 \%$ of the viable seed sown. Type of seedbed significantly affected establishment with lowest legume density measured in the control (heavy grazing only) followed in ascending order by the cultivated, disked, and herbicide treatments. In the establishment year, Seca stylo stands were twice as dense as Verano in all treatments except the control (Fig. 2). However, density increased $(P<0.05)$ in all seedbeds with time. For Verano, populations doubled with each successive year, but the densities were still lower $(\mathrm{P}<0.05)$ than Seca in 3-year-old swards in all seedbeds (Fig. 2). The superiority of the herbicide treatment was maintained throughout the 3-year study (Fig. 2).

\section{Production}

Legumes: Seedbed type, legumes species, and time significantly affected legume performance (Table 3). Yields measured at the end of the first growing season for Verano and Seca were less ( $P$ $<0.05$ ) on the control and cultivated plots than on the disked or herbicide treatments (Fig. 2). Despite the difference in density,
Table 3. Means for main effects of production for Verano and Seca stylo sown on 4 seedbeds on sandy soil at Gaopoling Farm, 1981-1983 (Experiment 2).

\begin{tabular}{|c|c|c|c|c|}
\hline \multirow{2}{*}{$\begin{array}{l}\text { Main } \\
\text { Effect }\end{array}$} & \multirow[b]{2}{*}{ Comparison } & \multicolumn{3}{|c|}{ Parameter } \\
\hline & & Legume $^{l}$ & Other spp & Total \\
\hline \multirow{5}{*}{ Seedbed } & & \multicolumn{3}{|c|}{$\ldots \ldots\left(t \mathrm{DM} \mathrm{ha}^{-1}\right) \ldots \ldots \ldots$} \\
\hline & Heavily grazed & $1.73 \mathrm{c}$ & $0.74 \mathrm{~b}$ & $2.47 \mathrm{~b}$ \\
\hline & Herbicide & $2.64 a$ & $0.75 b$ & $3.39 \mathrm{a}$ \\
\hline & Disked & $2.11 \mathrm{~b}$ & $1.04 \mathrm{a}$ & $3.15 \mathrm{a}$ \\
\hline & Cultivated & $1.08 \mathrm{~d}$ & $1.02 \mathrm{a}$ & $2.10 \mathrm{c}$ \\
\hline \multirow{2}{*}{ Legume } & Verano & $1.22 \mathrm{~b}$ & $0.82 \mathrm{~b}$ & $2.04 \mathrm{~b}$ \\
\hline & Seca & $2.57 \mathrm{a}$ & $0.99 \mathrm{a}$ & $3.56 \mathrm{a}$ \\
\hline \multirow[t]{3}{*}{ Year } & 1981 & $0.37 \mathrm{c}$ & $1.12 \mathrm{a}$ & $1.49 \mathrm{c}$ \\
\hline & 1982 & $2.09 \mathrm{~b}$ & $1.04 \mathrm{a}$ & $3.13 \mathrm{~b}$ \\
\hline & 1983 & $3.21 \mathrm{a}$ & $0.55 \mathrm{~b}$ & $3.76 a$ \\
\hline
\end{tabular}

Main effects means within paraneters followed by the same letter are not significantly

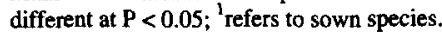

yields were similar for the 2 stylos on each seedbed at the end of the first wet seuson. However, in 2- and 3-year-old pastures the production of Seca always exceeded that of Verano by 0.3 to $4.2 \mathrm{t}$ $\mathrm{ha}^{-1}$; the difference being least in the cultivated plots and greatest in the herbicide treatment. Plant density and legume yield were highly correlated $(P<0.01)$ explaining $85 \%$ of variation in Verano yield and $77 \%$ for Seca. At the end of the third year, the effects of seedbed on legume production were still evident: yield of both stylos was still lowest in the cultivated plots and highest in the disked (Verano) or herbicide (Seca) seedbeds (Fig. 2).

Other species: A significant interaction $(\mathrm{P}<0.01)$ occurred between legume species, seedbed preparation, and time. Higher yields $(P<0.05)$ of endemic grasses and forbs were measured in the disked and cultivated treatments where the soil was disturbed (Table 3), and lower yields where legume production exceeded 2 $\mathrm{t} \mathrm{ha} \mathrm{a}^{-1}$ for Verano and $3 \mathrm{tha}^{-1}$ for Seca (Fig. 2) which occurred in 2- or 3-year-old swards on some seedbeds. Regression analysis showed that yield of both legumes accounted for $>55 \%$ of the variability in production of companion species. By 1983, other species accounted for $<10 \%$ of Seca-based pastures whereas for Verano pastures grass and forbs made up $>25 \%$ of the total yield.

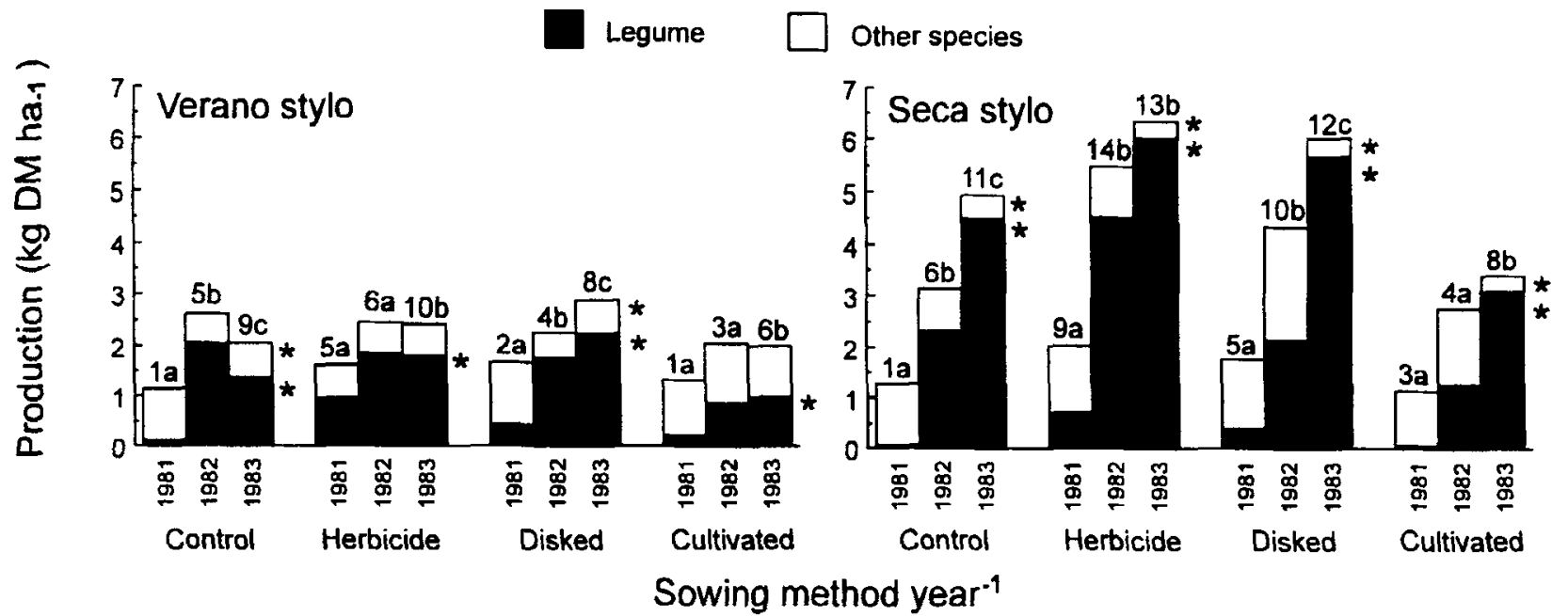

Fig. 2. Establishment (plants $\mathrm{m}^{-2}$ ) and production (kg DM/ha) for Verano and Seca stylo broadcast on differently prepared seedbeds on sandy soil at Gaopoling Farm, 1981-1983 (Experiment 2). Numbers above histogams are densities (plants m $^{-2}$ ) of verano measured in September each year. Densities followed by the same letter are not significantly different at $P<0.05$ between years within seedbed types. Asterisk indicate significant differences at $P<0.05$ in legume or "other species" production between years within seedbed types. 
Total yield: Total yield was highest where herbicide and disking were used to check native pasture growth prior to broadcasting legume seed, and lowest on the cultivated seedbed (Table 3). Seca-based pastures produced twice the forage output of Veranobased pastures. In general, total production increased over time with yield of 3-year-old pastures exceeding $(P<0.05)$ that of 1 year-old pastures for both legumes (Fig. 2). This was due in all instances to the performance of the sown legume.

\section{Experiment 3}

\section{Establishment}

Seedbed type and time both had a large effect $(P<0.01)$ on Verano density. Overall herbicide and disked treatments produced $50 \%$ more plant $\mathrm{m}^{-2}$ than the heavily grazed or burnt plots (8.2 vs 5.2). The effect of seedbed was greatest in the establishment year with Verano populations in the 2 best treatments being 3 times as dense as the heavily grazed or burnt plots (Fig. 3). Although Verano density increased exponentially with time in all treatments, the effect of seedbed type remained with the herbicide treatment still having the highest $(P<0.05)$ legume population in 1983 (Fig. 3). Fertilizer rate did not affect legume density.

\section{Production}

Legumes: Seedbed preparation, fertilizer rate, and age of pasture all significantly affected $(P<0.05)$ legume production (Table 4). Verano yield in the heavily grazed seedbed (control) was much lower $(P<0.05)$ than in other seedbed types. Plants were small and spindly in the $\mathrm{P0}$ and $\mathrm{P} 7$ fertilizer treatments, and Verano production only exceeded $0.75 \mathrm{tha}^{-1}$ at the highest fertilizer rate in 1983 (Fig. 3).

Burning prior to broadcasting seed improved Verano yield over the control, especially when combined with fertilizer (P28) which resulted in a three-fold increase in the production of Verano in the establishment year (Fig. 3). However, by 1983 Verano yields were similar on control and burnt seedbeds at any fertilizer level.

Establishment year production of Verano on disked seedbeds was not significantly different from that measured on the burnt seedbed at any fertilizer level. However, in the second year, Verano response on disked seedbeds was twice that of the burnt seedbed at equivalent $\mathbf{P}$ input, but this difference was only sustained at the highest $P$ rate in 3-year-old swards (Fig. 3).

Table 4. Means for main effects of production for Verano stylo sown on 4 seedbeds on sandy soil with 4 rates of superphosphate at Gaopoling Farm, 1981-1983 (Experiment 3).

\begin{tabular}{lllcc}
\hline \hline Main & & \multicolumn{3}{c}{ Parameter } \\
\cline { 3 - 5 } Effect & Comparison & Legume $^{1}$ & Other spp & Total \\
\hline \multirow{3}{*}{ Seedbed } & Heavily grazed & $0.21 \mathrm{~d}$ & $1.65 \mathrm{~b}$ & $1.86 \mathrm{c}$ \\
& Herbicide & $1.65 \mathrm{a}$ & $0.56 \mathrm{~d}$ & $2.21 \mathrm{~b}$ \\
& Disked & $1.12 \mathrm{~b}$ & $1.36 \mathrm{c}$ & $2.48 \mathrm{ab}$ \\
& Burnt & $0.70 \mathrm{c}$ & $1.97 \mathrm{a}$ & $2.67 \mathrm{a}$ \\
Fertilizer & $\mathrm{P}_{0}$ & $0.53 \mathrm{~d}$ & $1.23 \mathrm{a}$ & $1.76 \mathrm{~d}$ \\
& $\mathrm{P}_{7}$ & $0.76 \mathrm{c}$ & $1.40 \mathrm{a}$ & $2.16 \mathrm{c}$ \\
& $\mathrm{P}_{14}$ & $1.04 \mathrm{~b}$ & $1.44 \mathrm{a}$ & $2.48 \mathrm{~b}$ \\
& $\mathrm{P}_{28}$ & $1.34 \mathrm{a}$ & $1.45 \mathrm{a}$ & $2.79 \mathrm{a}$ \\
& 1981 & $0.46 \mathrm{c}$ & $1.06 \mathrm{~b}$ & $1.52 \mathrm{c}$ \\
Year & 1982 & $1.40 \mathrm{a}$ & $1.53 \mathrm{a}$ & $2.93 \mathrm{a}$ \\
& 1983 & $0.90 \mathrm{~b}$ & $1.56 \mathrm{a}$ & $2.46 \mathrm{~b}$ \\
\hline
\end{tabular}

Main effects means within parameters followed by the same letter are not significantly different at $P<0.05$.
The herbicide seedbed produced the most vigorous Verano swards. This was not due to higher establishment year production, but to superior Verano yield in subsequent years. In 2-yearold swards, Verano yield was higher $(\mathrm{P}<0.05)$ than the disked seedbed at the lower $P$ rates, and at all $P$ rates in 3-year-old pastures. Further, Verano production on the herbicide seedbed did not decline significantly in the third year as was the case in the other seedbed types (Fig. 3).

Other species: Seedbed type and time significantly affected production of companion grasses (about $90 \%$ of "other species" category) and forbs (10\%), but these endemic species did not respond to $\mathbf{P}$ fertilizer. Herbicide application reduced the yield of other species to less than half that of the heavily grazed seedbed with the effect extending into the third seasons (Fig. 3). Disking also reduced the growth of companion species in the establishment year, but the effect was lost in 2-year-old swards. In contrast, burning tended to increase the yield of the native species in 2- and 3-year-old pastures, although this only reached significance in 1983 at the higher rates of $P$.

Total yield: Total yield was lowest on the heavily grazed seedbed (control) and highest on the disked and burnt treatments (Table 4). Fertilizer application increased total yield on average by about $1 \mathrm{t} \mathrm{DM} \mathrm{ha-1}$. Unlike in Experiment 2, total yield was higher in 1982 than 1983 (Table 4). This was due to a decline in Verano production in 3-year-old pastures, especially on the disked seedbed where total yield declined by 1.5 and $2 \mathrm{t} \mathrm{DM} \mathrm{ha}^{-1}$ between years (Fig. 3).

\section{Discussion and Management Implications}

Based on research conducted in northern Australia, broadcasting seed of new species into existing stands of native pasture has become a popular and cost-effective means of improving production from tropical rangelands throughout the world. To perform this role, pasture species must be easy to establish, persistent, and have the ability to compete with native species against tackground constraints of low soil fertility, regular drought, variable grazing pressure and periodic fire (Miller and Stockwell 1991).

Seedbed preparation is a critical factor which influences the speed and success of establishment and subsequent production of oversown grasses and legumes. Sowing methods developed in Australia for establishing pasture species in tropical rangelands provide a range of conditions mainly through differences in soil and vegetation disturbance to optimise soil-seed contact and/or minimise competition from existing vegetation (Cook et al. 1993b).

This series of experiments has highlighted the effects of different seedbed types ranging from complete removal of existing pasture by multiple cultivations to a simple heavy grazing prior to broadcasting seed on the performance of selected grasses and legumes in the dry tropical (annual rainfall $<1,010 \mathrm{~mm}$ ) environment of western Hainan Island.

\section{Effects of Seedbed Type on Legume Establishment Heavily grazed seedbed}

All 3 experiments demonstrated that in the rainfall conditions experienced, Stylosanthes species will establish on sandy and red loam soils by broadcasting seed and superphosphate into grass dominated rangeland where heavy grazing was the only source of pre-sowing disturbance. However, the result achieved varied with 


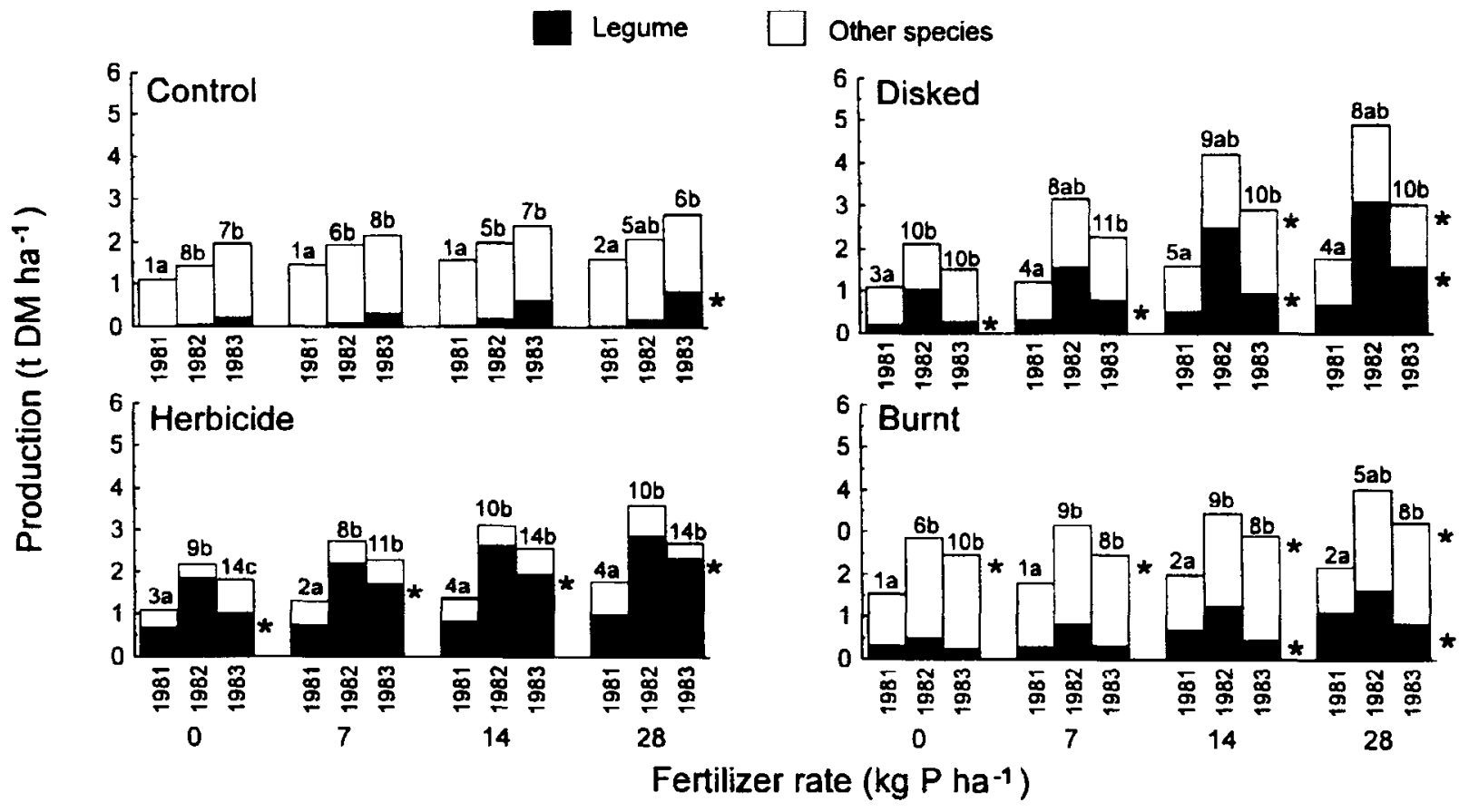

Fig. 3. Establishment (plants $\mathrm{m}^{-2}$ ) and production (t DM ha-1) for Verano stylo broadcast on differently prepared seedbeds on sandy soil using different rate of $P$ fertilizer at Gaopoling Farm, $f$ 1981-1983 (Experiment 3). Numbers above histograms are densities (plants m $^{-2}$ ) of verano measured in September each year. Densities followed by the same letter are not significantly different at $P<0.05$ in legume or “other species" production between years within fertilizer treatments and seedbed types.

the native grass species present, the post-planting management imposed, and the legume species sown.

For example, different responses were observed in 3-year-old swards of Verano stylo established by broadcasting seed into pregrazed pasture with higher production in Experiment 2 compared with Experiments 1 and 3. This was due to differences in the native species present on these sites and management of the experiments. The sites for Experiments 1 and 2 were dominated by stoloniferous grasses (e.g. Cynodon dactylon) with only a few taller bunch grasses present, whereas Experiment 3 was dominated by tall grasses, especially Imperata cylindrica and Heteropogon contortus. Like Townsville stylo ( $S$. humilis H.B.K.), Verano stylo is sensitive to inadequate light, and in Experiment 3, these tall grasses shaded Verano seedlings which restricted plant development.

To reduce shading effects and competition, Verano pastures should be grazed at an early stage of growth during the establishment year (Tudsri et al. 1989). The effect of this strategy was shown by the difference in Verano performance in Experiments 1 and 2 where yield in 3-year-old pastures in ungrazed plots (Experiment 1) was only half that where swards had been under continuous graze throughout the wet season. Gardener (1984) reported that such grazing favours Verano because cattle have a preference for grass over legume in the growing season.

In contrast to Verano, there was no difference in the establishment and subsequent production of Seca stylo broadcast into existing heavily grazed pasture on sandy soil with different native grass composition (Experiments 1 and 2). This was unexpected as Seca is reported to be slow to germinate and establish (Gardner 1978). However, once established this shrubby perennial is not susceptible to shading by tall grasses (Burt et al. 1983) and unless checked by grazing will quickly dominate the pasture as shown by this study and a report by Jones (1990).

\section{Burning}

Like heavy grazing, burning tropical rangeland as a pre-treatment to oversowing is designed to reduce competition for light, but since root competition is only slightly reduced, results achieved with burning are equivocal (Cook et al. 1993a). However, our results (Experiment 3) showed that Verano stylo established better on burnt plots and were still more productive as 3-year-old swards than where heavy grazing was used to reduce competition. Thompson et al. (1983) also reported reliable establishment of Stylosanthes species on burnt seedbeds at 4 different environments in dry tropical Queensland, but they did not provide data on subsequent production.

Concurrent and/or post-establishment management is critical for development of an acceptable proportion of legume wherever low cost seedbeds are used. For example, higher rates of superphosphate improved the legume content on burnt plots in Experiment 3 , which would have been increased still further with the imposition of the grazing strategy outlined by Tudsri et al. (1989).

Occurrence of wildfires can also have a significant effect on grass-legume balance in established pastures with fire generally favouring perennial grasses. The tolerance of stylos such as Seca to fire could enable burning to improve pasture quality by removing aged woody growth and dead grass. However, the response of stylos to a wildfire that burnt the loam site in 1983 (Experiment 1) indicate that the intensity of fire may affect the outcome. In this study, the recovery of Seca was much lower than that reported by Michalk et al. (1993a) for an adjacent legume evaluation study. Although the reason for this is uncertain, we suggest that the fire was hotter in the seedbed trial site due to the combined bulk of the legumes and the considerable scrub cover (not included in yield assessment) which was present in the uncultivated 
seedbeds. Gardner (1980) showed that even for Seca (the most fire tolerant stylo cultivar) severe fires killed more than $70 \%$ of existing plants. Unlike Graham stylo which quickly re-established from soil seed reserves softened by the August fire to produce up to $4 \mathrm{t} \mathrm{ha}^{-1}$ by November, low seed reserves and slow seedling growth meant that Seca yield $\left(<1 \mathrm{t} \mathrm{ha}^{-1}\right)$ over the same period came from the few surviving plants. These observations support the recommendation of sowing mixtures of Seca with either Graham or Verano (Michalk et al. 1993a) to complement one another in situations where fire or disease may occur.

\section{Rough disked seedbed}

Rough seedbeds are formed by 1 pass of a disk or tyne implement with the aim of partially disturbing the existing pasture to facilitate establishment of sown species (Cook et al. 1993b). Usually less than $70 \%$ of the existing pasture is destroyed by a single disking (Lowe and Bowdler 1991) which leaves too much competition for reliable establishment in some environments, especially in years of below average rainfall (Cook et al. 1993a).

However, broadcasting seed and fertilizer on a roughly disked seedbed (Experiments 2 and 3 ) proved to be an effective means of establishing Seca and Verano stylos even though the studies were late sown and the rainfall below average. Shelton and Wilaipon (1984) also achieved good establishment by broadcasting Verano into a rough seedbed with subsequent production exceeding that of non-cultivated areas by up to $3.5 \mathrm{t} \mathrm{ha}^{-1}$. Better moisture regimes or less competitive grasses may explain these results. McIvor and Gardner (1985) reported that a similar situation exists in the dry tropics of northern Queensland.

\section{Use of herbicides}

Herbicides provide a convenient way to suppress competing plants when surface sowing is undertaken. Translocated herbicides such as glyphosate applied at low rates suppress a wide range of perennial grasses. In Experiments 2 and 3, glyphosate retarded existing vegetation sufficiently for stylos to establish and produce the highest first year yield of all the seedbed types tested. Effects of herbicide application were still evident after 3 years in Experiment 3 with Verano accounting for by $>80 \%$ of total yield when combined with superphosphate application.

Removal of a large proportion of the green and dead native forage by heavy grazing with cattle prior to herbicide application maximized the chancc of seed-soil contact in our studies as well as enhancing herbicide to green leaf contact. Failure to remove top growth will reduce germination and establishment of introduced species. For example, Keya et al. (1972) obtained successful establishment of Desmodium uncinatum (Jacq.) DC, after spraying Hyparrhenia grassland, but heavy litter buildup tended to trap seed and smother developing seedlings. McIvor and Gardener (1981) also reported that the failure to remove the large amount of herbage prior to spraying with glyphosate also reduced germination of sown grasses.

\section{Cultivated seedbed}

Drilling seed into well-prepared soil at the optimum depth for the pasture species being sown provides the best conditions for germination and seedling emergence through oplimizing soilseed contact (Cook et al. 1993b). However, depth of sowing can be a problem with small seeded species planted into a fine tilth cultivated seedbed. Burial of stylo seed too deeply in the drill furrow depressions by trailing harrows in Experiment 2 resulted in lower density of Verano and Seca compared to Experiment 1 where stylo seed was surface broadcast and lightly raked.

Cheap mechanical aids that can be fitted to combine drills have been developed to place seed at a consistent shallow 5 to $10-\mathrm{mm}$ depth (Butt 1988). Such options are likely to be highly cost effective as failure of seed to emerge is a common problem of grasses and legumes being sown too deeply (Cook et al. 1993b). Alternatively, seed can be dropped onto the surface so that seeds lodge in depressions and crevices with only minimal coverage as was achieved in Experiment 1.

However, while combine drills and associated equipment may be used on large commercial ranches (e.g. ex-state farms like Gaopoling Farm), cultivation using ox drawn plows and hand broadcasting are the means available for improving small holdings in southern China. For medium size areas, small tractors (< 50 h.p) with 1-way disk plows to produce rough seedbeds are readily available.

The negative effect of the cultivated seedbed was still evident in 3-year-old swards with production of Verano and Seca still significantly lower than where other seedbed preparation were used. However, competition from native species is the most likely cause of lower plant densities in 1982 and 1983 measured on the prepared seedbed.

\section{Effects of Seedbed Preparation on Grasses Establishment}

Unlike legumes, the reliability of using minimum seedbed preparation to establish grasses is low. Grass establishment in Experiment 1 was only successful with maximum disturbance of the existing pasture. This agreed with results reported by Cook (1984) and Low and Bowdler (1991), although McIvor and Gardener (1981) reported that sabi grass and rhodes grass (Chloris gayana Kunth.) established when broadcast into a native pasture pre-treated with herbicide. Because of the poor success rate reported at the time for grass establishment on herbicide seedbeds, the role of glyphosate in establishing grasses was not examined in our studies.

The failure of buffel and sabi to establish and be productive even with good seedbed preparation is an indication of their intolerance of low soil fertility and poor competitiveness with companion legumes and native pasture species. While the fertilizer applied ( $28 \mathrm{~kg} \mathrm{P} \mathrm{ha}^{-1}$ ) in Experiment 1 proved sufficient to maintain the legume component on the infertile sandy soil, higher $P$ inputs and application of $\mathrm{N}$ may be required to maintain or improve performance of sown grasses. Other studies at Gaopoling Farm indicate that a doubling of the superphosphate rate increased buffel grass yield to $1 \mathrm{t} \mathrm{ha}^{-1}$ in the establishment year on sandy soil (D.L. Michalk, unpublished data). This has also been reported for $S$. hamata-U. mosambicensis pastures in northern Australia where sabi grass only became dominant with high applications of superphosphate (McIvor 1984). The use of $50 \mathrm{~kg} \mathrm{~N}^{-1} \mathrm{ha}^{-1} \mathrm{yr}^{-1}$ also improved the performance of sown grasses in dry tropical Hainan, especially on red loam soil (Michalk et al. $1993 \mathrm{~b}$ ), but this was only profitable where grass response exceeded $4 \mathrm{t} \mathrm{ha}^{-1} \mathrm{yr}^{-1}$ and neither buffel grass or sabi grass responded to this level. 


\section{Recommendation and Conclusions}

We recommend that range improvement on sandy soils in the dry tropics of Hainan Island be based mainly on stylos broadcast with small amounts of fertilizer into the natural grasslands after competition is reduced by heavily grazing, burning, or rough disking. Of these seedbeds, stylo establishment is most reliable when rough disking is used with the effects on legume performance carried through to subsequent years. Although full productivity is not reached for 2-3 years, burning and heavy grazing provide useful low-cost means of introducing stylos into native vegetation in China. This suggests that irrespective of the seedbed type selected, the success of establishment and long-term persistence of stylos will depend on the adoption of grazing practices which encourage seedling recruitment in subsequent years and fertilizer application (Michalk et al. 1997). Although herbicides greatly reduced competition which increased legume production, products such as glyphosate are expensive and supplies limited.

For establishment of introduced grasses substantial disturbance of vegetation is required. We recommend that a rough to fine seedbed be used for grasses, irrespective of soil type. Since competition is the factor which most limits establishment, the effect of herbicides on grass establishment should be investigated. Where grasses are sown on a cultivated seedbed, we recommend that companion legumes be sown at the same time. However, there is no value in including introduced grasses with legumes oversown into native pasture on either soil type.

\section{Literature Cited}

Andrew, M.H. 1988. Rangeland ecology and research in the tropics in relation to intensifying management for livestock industry, p. 197-213. In: Panjab Singh, P.S. Panthak, Vinod Shankar, and A.K. Srivastava (eds.), Rangeland resources-management and utilization, Proc. Third Int. Range. Congr., Range Manage. Soc. India, Jhansi, India.

Burt, R.L., D.G. Cameron, D.F. Cameron, L.'t Mannetje, and J. Lenne. 1983. Stylosanthes, p. 141-186. In: R.L. Burt, P.P. Rotar, J.L. Walker, and M.W. Silvey (eds.), The role of Centrosema, Desmodium, and Stylosanthes in improving tropical pastures, Westview Trop. Agr. Ser., No. 6., Westview Press, Boulder, Colo.

Butt, S. 1988. Band seeders for pasture establishment. NSW Agriculture, AgFact P2.E.1.

Cook, S.J. 1984. Establishment of four pasture grasses and Siratro from seed oversown into dense and open spear-grass pasture. Aust. J. Exp. Agr. Anim. Husb. 24:360-369.

Cook, S.J., M.A. Gilbert, and H.M. Shelton. 1993a. Tropical pasture establishment. 3. Impact of plant competition on seedling growth and survival. Trop. Grassld. 27:291-301.

Cook, S.J., R.L. Clem, N.D. MacLeod, and P.A. Walsh. 1993b. Tropical pasture establishment. 7. Sowing methods for pasture establishment in northern Australia. Trop. Grassld. 27:335-343.

Gardener, C.J. 1978. Seedling characteristics of Stylosanthes. Aust. J. Agr. Res. 29:803-813.

Gardener, C.J. 1980. Tolerance of perennating Stylosanthes plants to fire. Aust. J. Exp. Agr. Anim. Husb. 20:587-593.

Gardener, C.J. 1984. Dynamics of Stylosanthes pastures. p. 333-345. In: H.M. Stace and L.A. Edye (eds.), The biology and agronomy of Stylosanthes, Academic Press, Sydney.

Grubov, V.I. 1969. Flora and vegetation. p. 265-364. In: USSR Acad. Sci. Inst. Georg. The physical geography of China. Vol. 1. F.A. Oraeger Publishers, New York.

Hu, Shing Tsung, D.B. Hannaway, and H.W. Youngberg. 1992. Forage resources of China. Pudoc Wageningen.
Hutton, E.M. 1979. Problems and successes of legume-grass pastures, especially in tropical Latin America, p. 81-94. In: P.A. Sanchez and L.E. Tergas (eds.), Pasture production in acid soils of the tropics, CIAT, Cali, Colombia.

Jones, R.J. 1990. Phosphorus in beef production in northern Australia. 1. Phosphorus and pasture productivity-a review. Trop. Grassl. 24:131-139.

Keya, N.C.O., F.H. Olsen, and R. Holliday. 1972. Comparison of seed beds for oversowing Chloris gayana (Kunth.) Desmodium uncinatum (Jaq.) mixture in Hyparrhenia grassland. E. Efr. Agr. For. J. 37:286-293.

Lowe, K.F. and T.M. Bowdler. 1991. The effect of seedbed and sowing time on establishment of siratro and Gatton panic into native pasture. Trop. Grassl. 25:37-46.

McIvor, J.G. 1983. The effect of seedbed preparation and sowing time on the establishment of perennial Stylosanthes species. Trop. Grassl. 17:82-85

McIvor, J.G. 1984. Phosphorus requirements and responses of tropical pasture species: native and introduced grasses, and introduced legumes. Aust. J. Agr. Res. 24:370-378.

McIvor, J.G. and C.J. Gardener. 1981. Establishment of introduced grasses at different stages of pasture development: Effects of seedbeds. Aust. J. Exp. Agr. Anim. Husb. 21:17-38.

McIvor, J.G. and C.J. Gardener. 1985. Germination of introduced pasture species in the semi-arid tropics, p. 277-279. In: J.G. Tothill and J.J. Mott (eds.) Ecology and management of the world's savannas. Australian Acad. of Sci., Canberrra.

Michalk, D.L., Fu Nan-Ping, and Zhu Chin-Ming. 1993a. Improvement of dry tropical rangelands in Hainan Island, China: 1. Evaluation of pasture legumes. J. Range. Manage. 46:331-339.

Michalk, D.L., Fu Nan-Ping, and Zhu Chin-Ming. 1997. Improvement of dry tropical rangelands on Hainan Island, China: 3. Legume response to initial fertilizer J. Range Manage. 51:97-105.

Miller, C.P. and T.G.H. Stockwell. 1991. Sustaining productive pastures in the tropics 4 . Augmenting native pasture with legumes. Trop. Grassld. 25:98-103.

Norman, M.J.T. 1967. Companion grasses for Townsville lucerne at Katherine, N.T.J. Aust. Inst. Agr.. Sci., 33:14-22.

Payne, R.C. and Committee. 1988. Genstat 5 Reference Manual. Oxford, Univ. Press, Oxford, England.

Ritson, J.B., L.A. Edye, and P.J. Robinson. 1971. Botanical composition of Townsville stylo-spear grass pasture in relation to conception rates of cows. Aust. J. Agr. Res. 22:993-1007.

Shelton, M.H. and B. Wilaipon. 1984. Establishment of two Stylosanthes species in communal grazing areas of northeast Thailand. Trop. Grassld. 18:180-185.

Thompson, D.P., J.G.McIvor, and C.J. Gardener. 1983. The effect of seedbed type on establishment of legumes and grasses at four sites in north Queensland. Trop. Grassl. 17:3-10.

Tudsri, S. B.R. Watkin, S. Chantkam, A.C.P. Chu, and B.J. Forde. 1989. Effect of first year grazing management on Stylosanthes hamata cv. Verano production at Muak Lek, Saraburi, Thailand. Trop. Grassld. 23:35-42.

Walker, J.L. 1983. Introduction, p. 1-3. In: R.L. Burt, P.P. Rotar, J.L. Walker, and M.W. Silvey (eds.), The role of Centrosema, Desmodium, and Stylosanthes in improving tropical pastures, Westview Trop. Agr. Ser., No. 6., Westview Press, Boulder, Colo.

Winks, L., F.C. Lamberth, K.W. Moir, and P.M. Pepper. 1974. Effect of seedbed type and fertilizer on the performance of steers grazing Townsville stylo-based pastures in north Queensland. Aust. J. Exp. Agr. Anim. Sci. 15:146-154. 